Jurnal Profesional Fisioterapi

E-ISSN: XXXX-XXXX | P-ISSN: XXXX-XXXX

Vol 1 No 1, Januari (2022)

\title{
Potensi Cidera Pada Olahraga Hapkido Provinsi Lampung
}

\author{
Efraldo Yudistira', Al Um Aniswatun Khasanah ${ }^{2}$, Novi Sefriana ${ }^{3}$ \\ 1,2Program Studi DIII Fisioterapi, Universitas Muhammadiyah Metro, Metro, Lampung \\ ${ }^{3}$ STKIP Rosalia Lampung, Metro, Lampung
}

efraldoy@gmail.com

\begin{abstract}
ABSTRAK
Injury conditions in martial arts based on epidemiological research are in the 10th position in dangerous sports with the potential for injury to reach $2.4 \%$ overall. The injury model that occurs each time is determined by a certain dominance technique of a discipline resulting from the philosophy of the sport discipline, training objectives, as well as from the rules of sports competition. The management of hapkido Lampung is aware of the lack of facilities for approaching medical science in injury management to review data and carry out training developments to minimize injuries.This study purpose was to determine the risk of injury to Hapkido Athletes in order to develop training programs to focus on preventing or reducing the potential for existing injuries so that athletes have maximum performance.

This research is descriptive analytic research using cross sectional design . In this design a transverse approach is used. Where is the observation of the independent variable and the dependent variable is carried out only once at the same time with the number of research samples 60 . The results of this study are data on the incidence of injuries experienced by hapkido athletes based on questionnaire data collection. The data obtained are $53.3 \%$ female samples and $46.7 \%$ male, with data on the incidence of injury $50.9 \%$ in the ankle region, and $44.4 \%$ specific tissue injury to joints and ligaments and the incidence of injury during technical training $50.9 \%$. The incidence rate of injury to the hapkido martial arts athlete in Lampung has the largest presentation in the ankle region and in specific ligamentous tissues with the risk of it occurring during movement technique training activities where the results can be concluded that hapkido sports require good joint stability, especially in the ankle region.
\end{abstract}

Kata Kunci: Injury, Hapkido, Movement Techqnique analysis.

\section{PENDAHULUAN}

Pembina daerah Hapkido Provinsi Lampung akan mempersiapkan Atlet dalam kejuaraan eksebisi pada event PON-XX yang akan di selenggarakan di Papua. Namun pihak Pembina menyadari terdapat kekurangan dalam penanganan cidera pada para atletnya, baik dalam bentuk program pencegahan dan upaya meminimalisir resiko cidera, maupun penanganan cidera yang sudah terjadi pada atletnya. Cidera olahraga terjadi ketika seluruh atau sebagian tubuh menghadapi kekuatan berlebihan di atas rentang yang dapat ditoleransi, cidera olahraga dapat membuat atlet absen dalam partisipasi dalam kompetisi (Aksoy et al., 2021

Manajemen cidera pada olahraga memerlukan klasifikasi penanganan dalam perawatan berdasarkan data kejadian cidera begitu pula dalam mengembalikan fungsi secara fisiologis dengan menggunakan metode terapi dan latihan yang efisien dan terukur (Cassell, 2012).Data kecenderungan cidera perlu didapatkan guna merumuskan latihan yang spesifik terhadap fundamental kriteria teknik gerakan olahraga tertentu, dimana data tersebut dapat membantu dalam intervensi selanjutnya dengan menggunakan metode FMS yang akan dapat merumuskan dan membuat program untuk meminimalisir cidera terjadi (Ransdell, 2016)

Seni bela diri umumnya dianggap sebagai salah satu disiplin olahraga yang paling banyak menimbulkan cidera Kondisi Cidera pada cabang olahraga beladiri berdasarkan penelitian epidemiologi berada dalam posisi ke 10 olahraga berbahaya atau olahraga memiliki potensi cidera mencapai $2,4 \%$ secara keseluruhan (Piotr \& Witkoś, 2012). Cidera dalam seni bela diri, terutama cidera olahraga, sangat bergantung pada disiplin atau gaya tertentu, model cidera yang terjadi setiap kali ditentukan oleh teknik dominasi tertentu dari suatu disiplin yang dihasilkan dari filosofi disiplin olahraga, tujuan pelatihan, serta dari aturan kompetisi olahraga. Taekwondo yang merupakan memiliki kesamaan dalam gerakan bertarung Hapkido memiliki presentase terbesar resiko cidera dibandingkan 5 beladiri lain seperti aikido, taichi, karate, kungfu, yaitu sebesar $59,2 \%$, Sebagian besar cidera, $68 \%$, terjadi selama latihan, kurang dari 32\%, selama kompetisi tetapi dalam kondisi yang parah (Del Vecchio, 2017).

Hapkido merupakan olahraga beladiri yang berasal dari Korea Selatan dimana gerakan basis dasar memanfaatkan tendangan, kuncian, bantingan (Cahyati, 2020) namun dalam pertandingan resmi metode kuncian sangat jarang dilakukan diakrenakan efektifitas dalam penilaian kompetisi lebih menguntungkan pada gerakan serangan tendangan dan pukulan. Dasar beladiri hapkido menggunakan kekuatan lawan untuk melumpuhkannya dimana terdapat 3 prinsip dalam beadiri ini yaitu keseimbangan, fleksibilitas, koordinasi gerakan. 
Jurnal Profesional Fisioterapi

E-ISSN: XXXX-XXXX | P-ISSN: XXXX-XXXX

Vol 1 No 1, Januari (2022)

Data-data screening cidera atlet akan dilakukan dalam program persiapan atlet menghadapi kejuaraan eksebisi PON Papua yang akan di gunakan untuk menidentifikasi kemungkinan resiko cidera yang akan di alami oleh atlet serta menggali informasi untuk perihal peningkatan potensi atlet dan peningkatan performa. Data tersebut pula dapat membantu dalam kondisi dimana atlet pasca cidera dapat memaksimalkan kembali performa guna kembali ke cabang olahraga setelah cidera dan untuk mengembangkan profil karakteristik atlet yang berpartisipasi dalam olahraga (Warren, 2018)

Pemusatan latihan pada atlet Hapkido Lampung saat ini di lakukan dengan pelatihan fisik yang general kepada setiap atlet, belum adanya pemusatan khusus dan pemeriksaan mendetail terhadap perorangan atlet sehingga dalam penanggulangan atau pemantauan terperinci terhadap cidera atlet dan pencegahan cidera belum maksimal dilakukan. Dimana saat ini terdapat beberapa atlet yang mengalami cidera baik dalam kondisi akut maupun kronis

Berdasarkan data diatas disimpulkan bahwa dalam persiapan atlet di perukan screening data cidera atlet guna sebagai informasi dasar untuk pengembangan latihan dan program meminimaisir cidera yang dapat dilakukan medis yang bergerak pada bidang bikomekanika dan latihan yaitu Fisioterapi

\section{METODE}

Penelitian ini menggunakan metode penelitian deskriptif analitik dengan menggunakan desain cross sectional pendekatan transversal, dimana observasi terhadap variabel bebas dan variabel terikat dilakukan hanya sekali pada saat yang sama.7 Sampel penelitian atlet Hapkido Lampung berjumlah 60 orang yang merupakan $20 \%$ dari populasi anggota keseluruhan (Gray, 2009). Penelitian dilakukan di bulan Juli 2021 dengan jumlah anggota 60 yang memenuhi kriteria inklusi altet Hapkido aktif berusia 17-30 tahun dan kriteria ekslusif atlet Hapkido pasif atau tidak dalam range usia yang di tentukan.

HASIL

Data karakteristik responden sebagai berikut:

\begin{tabular}{cccc}
\multicolumn{4}{c}{ Tabel 1 Data Karakteristik Responden } \\
\hline No & Karkteristik & $\mathrm{F}$ & $\%$ \\
\hline \multirow{4}{*}{ Usia } & & \\
1 & $17-21$ tahun & 49 & $81,7 \%$ \\
2 & $22-25$ tahun & 6 & $10 \%$ \\
3 & $26-30$ tahun & 5 & $8,3 \%$ \\
\hline \multirow{3}{*}{ Jenis Kelamin } \\
1 & Laki-laki & 28 & $46,7 \%$ \\
2 & Perempuan & 32 & $53,3 \%$ \\
& & & \\
\hline
\end{tabular}

Sumber: Data Primer 2021

Dari tabel 1 diketahui bahwa mayoritas responden berusia antara 17-21 tahun (81,7\%) dan berjenis kelamin perempuan $(53,3 \%)$. Data usia menggambarkan rerata atlet hapkido lampung berada pada usia terbaik dalam kemantapan fisik (Koray \& Mustafa, 2020)

Berikut adalah hasil data perihal cidera yang memiliki 3 karakteristik:

Tabel 2 Data Cidera

\begin{tabular}{cccc}
\hline No & Data cidera & $\mathrm{F}$ & $\%$ \\
\hline \multicolumn{4}{c}{ Jaringan spesifik } \\
Cidera & & \\
1 & Strain Muscle & 13 & $24,1 \%$ \\
2 & Trauma Injury & 17 & $31,5 \%$ \\
3 & Joint \& Ligament & 24 & $44,4 \%$ \\
\hline \multicolumn{4}{c}{ Regio Cidera } \\
1 & Leher & 2 & $3,8 \%$ \\
2 & Bahu & 4 & $7,5 \%$ \\
3 & Panggul & 3 & $5,7 \%$ \\
4 & Lutut & 9 & $17 \%$ \\
5 & Pergelangan kaki & 27 & $50,9 \%$ \\
6 & Pergelangan & 8 & $15,1 \%$ \\
& tangan & &
\end{tabular}

Sumber: Data Primer 2021 
Jurnal Profesional Fisioterapi

E-ISSN: XXXX-XXXX | P-ISSN: XXXX-XXXX

Vol 1 No 1, Januari (2022)

Dari data di atas didapatkan nilai cidera tertinggi pada jaringan spesifik sendi dan ligament $(44,4 \%)$ dengan regio kejadian tertingi pada pergelangan kaki atau ankle $(50,9 \%)$

Data selanjutnya merupakan aktifitas latihan atau kompetisi yang memiliki faktor tertinggi terjadinya cidera

Tabel 3 Data Kejadian Cidera

\begin{tabular}{cccc}
\hline No & Data kejadian cidera & $\mathrm{F}$ & $\%$ \\
\hline & Aktifitas & & \\
1 & Latihan Fisik & 14 & $26,4 \%$ \\
2 & Latihan Tehnik & 27 & $50,9 \%$ \\
3 & Kompetisi & 12 & $22,6 \%$ \\
\hline \multicolumn{4}{c}{ Sumber: Data Primer 2021 }
\end{tabular}

Dari data di atas didapatkan nilai kejadian cidera tertinggi pada saat melakukan aktifitas latihan teknik gerakan hapkido $(50,9 \%)$, dengan total kejadian cidera saat latihan antara latihan fisik dan teknik mencapai $77,3 \%$.

\section{PEMBAHASAN}

Cidera olahraga adalah cidera yang terjadi dalam aktivitas atletik atau berolahraga. Hal itu dapat terjadi karena benturan, teknik pelatihan yang buruk dalam praktik, peralatan yang tidak memadai, dan penggunaan peralatan yang berlebihan bagian tubuh tertentu, Cidera yang umum terjadi pada olahraga antara lain sprain pada otot, fraktur dan retakan tulang akibat benturan dan permasalahan pada persendian yang melibatkan sendi dan ligament(Arpit, 2014).

Orang dewasa lebih kecil berkemungkinan untuk mengalami cidera olahraga daripada anak-anak, yang kerentanannya ditingkatkan oleh refleks yang belum matang, ketidakmampuan untuk mengenali dan mengevaluasi risiko, dan koordinasi yang kurang berkembang. Tingkat cidera tertinggi untuk atlet yang berpartisipasi dalam kontak olahraga seperti beladiri, tetapi cidera paling serius terkait dengan aktivitas individu atau pada sesi latihan (Mark, 2004).

Pengurus Daerah Hapkido Provinsi Lampung paham sekali akan kebutuhan atletnya dalam penanggulangan cidera, mengetahui kondisi pemantauan cidera yang minim, manajemen tim hapkido yaitu selaku pengurus daerah memberi kesempatan kepada peneliti dalam mengumpulkan data terkait cidera yang telah terjadi pada atletnya, yang nantinya data tersebut menjadi tolak ukur dalam pengembangan latihan dan program pencegahan dan meminimalisir tingkat kejadian cidera agar performa atlet maksimal.

cidera dapat dilakukan program pencegahan apabila terdapat analisa data cidera sebelum melakukan program kepelatihan dan kompetisi (Mohammed, 2016).

Proses penyusunan program pencegahan cidera terdiri dari beberapa aspek, yang mencakup pendidikan tentang rehidrasi, nutrisi,termasuk pemantauan anggota tim berisiko cidera, dan pemantauan perilaku, keterampilan fisik, dan teknik (Roald, 2009).

Dalam penelitian ini didapatkan data rerata terbesar dalam kejadian cidera pada sample atlet hapkido lampung yang terjadi pada lingkup struktural sendi dan ligament, dengan alokasi regio terdampak pada pergelangan kaki dan kejadian cidera terjadi pada sesi latihan

Penelitian Ini sesuai dengan hasil yang di paparkan oleh (Adriana et al., 2019) menyatakan bahwa cidera regio ankle memiliki potensi besar dalam terjadinya cidera, hal ini di pengaruhi oleh basis tapakan baik dari alas kaki maupun keseimbangan yang berisiko apabila tidak stabil.

Resiko terjadinya cidera jaringan spesifik sprain ankle atau cidera pada ligament memiliki angka tertinggi dari keseluruhan jaringan spesifik lainnya menurut hasil penelitian (Pedro et al., 2020)

Kejadian ini disebabkan ankle merupakan salah satu sendi penggerak bawah yang memiliki kemampuan koordinasi yang tinggi sehingga apabila terjadi instability yang disebabkan beberapa faktor seperti tingkat latihan khusus proprioceptif dan latihan keseimbangan yang kurang, terdapat laxity pada persendian, kelemahan otot stabilisasi dan lainnya (Martin, 2013) sehingga pada saat penerimaan teknik gerakan latihan khusus saat memerlukan koordinasi yang tinggi pada tungkai akan mengalami keterbatasan toleransi kemampuan ankle yang berujung dengan cidera.

Faktor aktifitas saat terjadinya cidera memiliki tingkat tertinggi dalam kegiatan latihan dibandingkan saat berkompetisi hal ini di tuangkan dalam penelitian (Del Vecchio, 2017).Sebagian besar cidera, terjadi selama latihan, dan sebagian kecil terjadi pada saat kompetisi kompetisi tetapi dalam kondisi yang parah

Dengan data tersebut perlu diadakanya program individual altet terhadap pencegahan cidera sesuai dari hasil penelitian (Caparrós et al., 2016) yang menyatakan bahwa pelaksanaan program pencegahan cidera harus dilakukan dengan mempertimbangkan pemrograman tim dan bersifat individual untuk setiap atlet sesuai dengan risiko cideranya. 
Jurnal Profesional Fisioterapi

E-ISSN: XXXX-XXXX | P-ISSN: XXXX-XXXX

Vol 1 No 1, Januari (2022)

Data-data yang di kumpulkan berdasarkan kejadian cidera pada atlet hapkido di bawah naungan manajemen hapkido lampung tengah tidak serta-merta menjadi tolak ukur kepastian cidera tersebut menjadi mutlak akan terjadi pada atlet, faktor utama dari kejadian cidera tersebut antara lain program latihan, kesiapan fisik, atau kondisi kondisi batasan atlet secara anatomical yang pastinya berbeda setiap individu. Data tersebut membantu pihak kepelatihan guna memprogram secara khusus individual atlet terhadap latihan pencegahan cidera dan berharap dapat diaksanakannya kembali penelitian lanjutan guna melakukan screening mendetail terhadap performa atlet dengan metode functional movement screening.

Dalam penelitian ini dapat disimpulkan potensi cidera pada atlet hapkido lampung memiliki karakteristik pada saat program latihan dan dan tingkat rata-rata terbesar berada pada region pergelangan kaki dan terdampak pada jaringan spesifik sendi dan ligament.

\section{DAFTAR PUSTAKA}

Abou Elmagd, Mohammed. (2016). Common sports injuries. International Journal of Physical Education, Sports and Health.

Bager Roald, Engebretsen Lars. (2009) Sports Injury Prevention. Chichester, UK; Hoboken, NJ: Wiley-Blackwell,

Beers Mark H, MD, Robert Berkow MD. (2004). Common Sports Injuries. Section 5, Chapter 62 In The Merck Manual of Diagnosis and Therapy. Whitehouse Station, NJ: Merck Research Laboratories.

Caparros, Toni \& Alentorn-Geli, Eduard \& Myer, Gregory \& Ortís, Lluís \& Samuelsson, Kristian \& Hamilton, Bruce \& Rodas, Gil. (2016). The Relationship of Practice Exposure and Injury Rate on Game Performance and Season Success in Professional Male Basketball. Journal of Sports Science \& Medicine.

Debieux, Pedro. Wajnsztejn, Andre. Salomão Barbachan Mansur, Nacime. (2020). Epidemiology of injuries due to ankle sprain diagnosed in an orthopedic emergency room. SaoPaulo: Einstein Journal.

Erin Cassell, Emily Kerr, Angela Clapperton, (2012), Adult sports injury hospitalisations in 16 sports: the football codes, other team ball sports, team bat and stick sports and racquet sports, Melbourne : Monash Injury Research Institute

F.B.Del Vecchio, C.B. Farias, R.C. de Leon, A.C.C.A. Rocha,L.M.Galliano, V.S.Coswig. (2017), Injuries in martial arts and combat sports : Prevalence, characteristics and mechanisms, Paris : Sci Sport.

Gay, LR, Geoffrey E. Mills and Peter Airasian. (2009). Educational Research, Competencies for Analysis and Application. New Jersey: Pearson Education, Inc.

Kilic, Koray \& Ince, Mustafa. (2020). Youth athletes' developmental outcomes by age, gender, and type of sport. Alicante: Journal of Human Sport and Exercise.

Martin, Robroy \& Davenport, Todd \& Paulseth, Stephen \& Wukich, Dane \& Godges, Joseph. (2013). Ankle Stability and Movement Coordination Impairments: Ankle Ligament Sprains. The Journal of orthopaedic and sports physical therapy.

Meghan Warren,Monica R Lininger,Nicole J Chimera,and Craig A Smith. (2018), Utility of FMS to understand injury incidence in sports: current perspectives. Arizona: J Sports Med.

Michalik, Piotr \& Witkoś, Joanna \& Wodarska, Magdalena \& Cieślińska-Świder, Joanna. (2012). Physiotherapy and martial arts. Katowice: Physiotherapy: Pressing Issues of Everyday practice.

Misra Arpit. (2014). Common Sports Injuries: Incidence and Average Charges, U.S. Department of Health and Human Services: (ASPE Office of Health Policy).

Moré Pacheco, Adriana \& Meyer, Flavia \& Pacheco, Ivan \& Candotti, Cláudia \& Sedrez, Juliana \& Chaves, Renata \& Loss, Jefferson. (2019). Ankle Sprain Risk Factors: A 5-Month Follow-Up Study In Volley And Basketball Athletes. Revista Brasileira de Medicina do Esporte.. 


\section{Jurnal Profesional Fisioterapi}

E-ISSN: XXXX-XXXX | P-ISSN: XXXX-XXXX

Vol 1 No 1, Januari (2022)

Murşit Aksoy, Turgay Özgür, Bahar Odabaş Özgür, Deniz Demirci, Gökalp Gürel, Şahin Özen. (2021). Incidence of Sport Injury in Contact and Non-Contact Sport, Parma : Matiolli Progress in Nutrition.

Ransdell, Lynda. (2016). Functional Movement Screening (FMS): An important tool for female athletes, Arizona: Strength and conditioning journal.

Suci Cahyati. (2020). Martial Arts Hapkido Basic for Beginner, Yogyakarta: UNYPress. 